\title{
Development of Kedah Natural Tourism Object in the Development of Leuser Ecowisata Area in Gayo Lues Regency
}

\author{
Amir Wahyu', Suwardi Lubis ${ }^{2}$, Rujiman ${ }^{2}$ \\ ${ }^{1}$ Master Student in University of Sumatera Utara (USU), Medan, Indonesia \\ ${ }^{2}$ Lecturer in University of Sumatera Utara (USU), Medan, Indonesia \\ amir.khan1729@yahoo.co.id
}

\begin{abstract}
The aims of this study is to find out how the Development of Kedah Natural Tourism Object in the Development of Leuser Ecowisata Area. The descriptive method of this study using qualitative research. The result shows that the SWOT analysis, Kedah Nature Tourism Objects shows that the position of the Kedah Nature Tourism Objects is in quadrant 1, this indicates that Kedah Nature Tourism Objects are in a very favorable position where the power possessed by Kedah Nature Tourism Objects such as the entrance to the Leuser Mountain which is one of the World Heritage has interesting flora and fauna and beautiful natural panorama and the air is still cool and clean can cover weaknesses and threats such as lack of facilities and infrastructure, unprofessional management and so forth. This position also makes Kedah Nature Tourism Objects can take all the opportunities available such as making Kedah Natural Tourism Objects a place for flora and fauna research for students and potential souvenirs, and so on.
\end{abstract}

Keywords : development; Kedah natural tourism; lauser ecowisata; Gayo

\section{Introduction}

Aceh Province has many natural tourist attractions, one of which is in the Gayo Lues Regency, namely Kedah Nature Tourism Object. Most of the Gayo Lues Regency is an area of the Leuser Mountain National Park (TNGL) which has been declared a world heritage and the Kedah Nature Tourism Object is the main entrance to the Leuser Mountain Climbing route in the Penosan Sepakat village.

The management of Kedah Nature Tourism Objects is currently not well managed, such as management is still not professional, the lack of tourism activities, facilities and infrastructure is still inadequate, especially the road to Kedah Nature Tourism Objects that are still damaged, can only be passed by motorbikes from Penosan village boundaries Agree, the process of providing information has not been organized or has not been conveyed properly, and is still lagging behind in other areas of tourism in the area of Leuser Mountain such as Bukit Lawang and Tangkahan in Langkat Regency, North Sumatra. Seen from some of the many facilities that are lacking in Kedah Nature Tourism Objects such as: there are no lawn chairs, no addition of flower gardens, no outbound gardens, ole-ole (souvenir) sales, internet networks, and places of worship. On the other hand, the existing facilities at Kedah Nature Tourism Object are poorly maintained, lack of landfills (TPS), infrastructure development that has not been considered and there are no additional facilities and more effective promotions.

Based on data from the Gayo Lues County Tourism Service that local and foreign visitor data visiting Kedah Natural Tour Object in 2016 numbered 451 people, the year 2017 increased 1250 people whereas by 2018 visitors increased drastically 8014 people due to the opening of the cafél Puncak Lestari Ayu canteen around the Kedah Natural Tourism area in modern style. In addition to its beautiful natural panoramic view and clear streams, the Kedah Natural Tour Object also houses the still natural "Uning" waterfall, the mileage of the waterfall's location is about $2.5 \mathrm{~km}$ towards the South of Kedah Tour Object, attainable 1 
hour by foot. In terms of lodging, there are homesteads with a total of 9 , while hotels number 12 are in the Regency capital. By looking at the circumstances a management/strategy role is required for the delivery of good information for the Kedah Natural Tour Object in order for the wider public to know and be able to enjoy the facilities provided at the Kedah Natural Tour Object when visiting. The form of effort that can be made among other things by doing more planned and regular promotions so that the promotion can achieve the desired appropriate results, that is, well-delivered and easy information while increasing the interest of outside and local communities to better recognize tourist attractions either by direct or not means, as well as improve and add means and infrastructure to the comfort of tourists.

\subsection{Definition of Tourism}

\section{Review of Literature}

Etymologically the word tourism is identified by the word travel in English which is defined as a trip that is made many times from one place to another. On the basis of that also by seeing a situation and conditions when tourism can be interpreted as a planned trip carried out individually or in groups from one place to another with the aim to get satisfaction and pleasure.

Tourism (1987: 21) is a trip from one place to another, temporary, carried out individually or in groups in an effort to find a balance or harmony and happiness with the environment in the social, natural cultural and scientific dimensions. Many tourism experts and experts as well as tourism organizations that provide limits or understanding of tourism, but to unite the views (perceptions) of the Indonesian people towards tourism boundaries, the government makes the tourism restrictions that are embodied in Article 1 point 3 of Law No. 10 of 2009, which is meant by tourism is a variety of tourism activities and is supported by various facilities and services provided by the community, entrepreneurs, government and local governments (2012: 4-5). According to Law No. 10 of 2009 tourism businesses include tourist attractions, tourism areas, tourism transportation services, travel services, food and beverage services, provision of accommodation, organizing entertainment and leisure activities, tourism information services, tourism consulting services, tour guides, fun tourism, SPA and organizing meetings, incentive trips, conferences and exhibitions.

Tourism is also an industry that is able to produce rapid economic growth in providing jobs, increasing income and living standards. As a complex industry, tourism also supports other sectors such as lodging, transportation and handicraft and souvenir industries.

\subsection{Concept of Tourism Development}

The essence of Indonesian tourism (2012: 15) rests on the uniqueness, uniqueness and authenticity of a regional community in Indonesian territory. This essence becomes the basic concept in the development and development of Indonesian tourism, both at national and regional levels.

According to Sugiharto (2006: 26) development is an effort to advance, improve or improve something that already exists. Development is also one part of management that focuses on the implementation of cultural potential, which must be carried out in a span of time, how much systematic scarce can lead to the achievement of results, and the expected results achieved in management planning with very specific activities to achieve the vision, goals, and objectives. the goal of the plan. 
According to Suwantoro (1997: 55), states the development strategy aims to develop products that service quality, balanced, gradually. Based on the above definition, what is meant by the floating strategy is efforts made with the aim of advancing, improving, and improving the condition of tourism of an object and tourist attraction so that it is able to be established and crowded for tourists to visit and able to provide a good benefit for the community around objects and attractions and will further become income for the government.

\subsection{Community Participation}

Participation is defined as an effort to involve the community in an activity both in the form of statements and activities. Further explained participation is community participation in development programs. From various community participation many things can be absorbed, including a sense of competition, a sense of responsibility and solidarity.

Community participation according to Rukminto Adi (2008) is community participation in the process of identifying problems and potential in the community, selection and decision making about alternative solutions to deal with problems, implementing efforts to overcome problems, and community involvement in the process of evaluating changes that occur. Community participation in various stages of this change will make the community become more empowered and can have more resilience in the face of change. On the other hand, if the community is not much involved in various stages of change, only being passive in every change planned by the agents of change (for example, government agencies, NGOs or the private sector), the community tends to become more dependent (dependent) on change agent. If this happens continuously, then the community's dependence on the agents of change will increase.

Community participation is also the right and obligation of a citizen to contribute to the achievement of the group. So that they are given the opportunity to participate in development by contributing their initiative and creativity. The contribution of initiative and creativity can be conveyed in community group meetings or meetings that are both formal and informal. In meetings or group meetings, information can be shared between the government and the community. So in participation there is communication between the government and the community and between fellow community members.

\section{Research Method}

This research was carried out in Kedah Nature Tourism Object, Penosan Sepakat Village, Blang Jerango District, Gayo Lues Regency, Aceh Province. This area is one of the entrances to the Mount Lauser National Park.

The time of the study was conducted for 2 months from April 2019 to May 2019, while data analysis and thesis preparation were held for 2 months from June to July 2019.

This research was conducted by descriptive method using qualitative research. Qualitative research (1995: 26) as a research procedure that produces descriptive data in which there are attempts to describe, record, analyze and interpret current conditions occur, aims to obtain information about the current state and see the relationship between variables that exist. 


\section{Discussion}

Kedah Natural Tourism Object is a natural tourism object located in Penosan Sepakat village, Blang Jerango District, Gayo Lues Regency, Aceh. Besides that, Kedah Nature Tourism Object is a production forest and tourism area directly adjacent to Gunung Leuser National Park (TNGL). Kedah Nature Tourism Object is the entrance to the spectacular "longest" climb in Indonesia, with 2 peaks close to each other namely Leuser (3,319 m asl) and Loser (3,404 $\mathrm{m}$ asl) marked by the triangulation pillar, while the Leuser peak can be reached around 2 hour walk across the mountain ridge. Dominated by mountains of natural pine forests, moss and sub alpine forests that will not be forgotten for a traveler (The Great Hall of the Leuser Mountain National Park: Sumatra's Tropical Forest Heritage Book). Entering Leuser Mountain, a traveler must take care of a Conservation Area Entry Permit (SIMAKSI) at the Leuser Mountain National Park Office, Medan, North Sumatra Province (Appendix). Leuser and Loser peaks take an average of 7 to 8 days from the natural attractions of Kedah. (Mr. Jalli / manager of Kedah natural attractions and Guides)

The second path through the Agusen Village / British Kampung Gayo Lues Regency is the path considered to be the most challenging, one of which must cross the river 45 times. The third path through the Meukik gate in Southwest Aceh District, through this route the ascent to the two peaks takes about 12 days. The distance from Kedah Natural Attraction to the Capital District $2 \mathrm{~km}$ and to the Capital District District $15 \mathrm{~km}$.

The impact of this Kedah Natural Tourism Object is the opening of jobs such as a Guide / Tour Guide, opening a cafe / canteen, selling agricultural products such as fruits, vegetables, opening workshops and so forth.

Table 4.1 Function of the Gayo Lues District Forest Area

\begin{tabular}{|c|c|c|c|c|c|c|c|c|c|}
\hline \multirow{2}{*}{ No } & \multirow{2}{*}{ sub-district } & \multicolumn{6}{|c|}{ Forest Area Function (Ha) } & \multirow{2}{*}{ Total } & \multirow{2}{*}{$\begin{array}{c}\text { Percentage } \\
\%\end{array}$} \\
\hline & & TNGL & HL & HPT & HP & HPK & APL & & \\
\hline 1 & Blangkejeren & $4.426,03$ & 5625,46 & 715,81 & - & - & 5838,33 & $16.605,63$ & 2,99 \\
\hline 2 & Blangpegayon & $17.917,07$ & $7.058,73$ & - & - & - & $2.242,29$ & $27.218,09$ & 4,90 \\
\hline 3 & Kutapanjang & $17.594,26$ & $4.457,72$ & $1.310,08$ & - & - & $3.590,66$ & $26.952,72$ & 4,86 \\
\hline 4 & Blangjerango & $15.807,30$ & $11.193,43$ & $3.092,84$ & - & - & $8.148,13$ & $38.241,70$ & 6,89 \\
\hline 5 & Dabun Gelang & $20.630,58$ & $14.818,64$ & - & $1.758,90$ & - & $7.263,01$ & $44.471,13$ & 8,01 \\
\hline 6 & Rikit Gaib & - & $14.953,77$ & $3.634,65$ & $3.199,60$ & - & $4.619,83$ & $26.407,85$ & 4,76 \\
\hline 7 & Pantan Cuaca & - & $16.300,76$ & $2.879,59$ & - & - & $10.326,20$ & $29.506,55$ & 5,32 \\
\hline 8 & Terangun & 41,92 & $50.786,28$ & $2.726,60$ & - & 653,98 & $12.971,52$ & $67.180,30$ & 12,10 \\
\hline 9 & Tripe Jaya & - & $28.876,91$ & $6.576,17$ & - & - & $8.259,56$ & $43.712,64$ & 7,88 \\
\hline 10 & Pining & $28.663,10$ & $66.850,50$ & $5.743,18$ & $\begin{array}{l}25.423,8 \\
1\end{array}$ & - & $8.327,77$ & $135.008,36$ & 24,33 \\
\hline 11 & Putri Betung & $96.762,47$ & 152,21 & - & - & - & $2.771,41$ & $99.686,09$ & 17,96 \\
\hline & TOTAL & $201.842,7$ & $221.074,4$ & $26.678,9$ & $30.382,3$ & 653,98 & $74.358,71$ & $554.991,06$ & 100,00 \\
\hline \multicolumn{2}{|c|}{ Percentage $(\%)$} & 36,37 & 39,83 & 4,81 & 5,47 & 0,12 & 13,40 & 100,00 & \\
\hline
\end{tabular}

Source: Decree of the Minister of Environment and Forestry Number: SK.103 / MenLHK-II / 2015 dated 2 April 2015 concerning Amendment to the Minister of Forestry Decree Number SK.865 / Menhut-II / 2014 dated 29 September 2014 concerning the Forest and Conservation Areas of Aceh Province. 


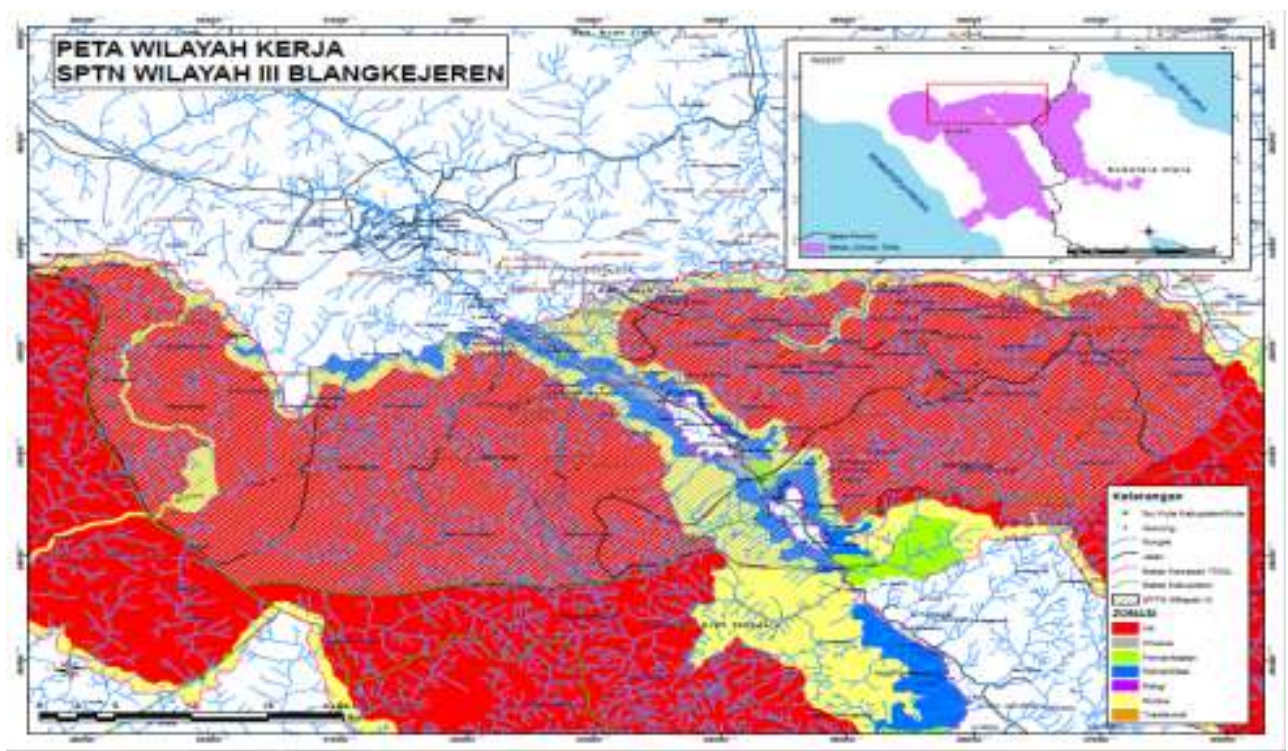

Source: SPTN Region III Blangkejeren Balai Besar Leuser mountain National Park

Figure 4.1 Map of the Kedah Nature Tourism Object

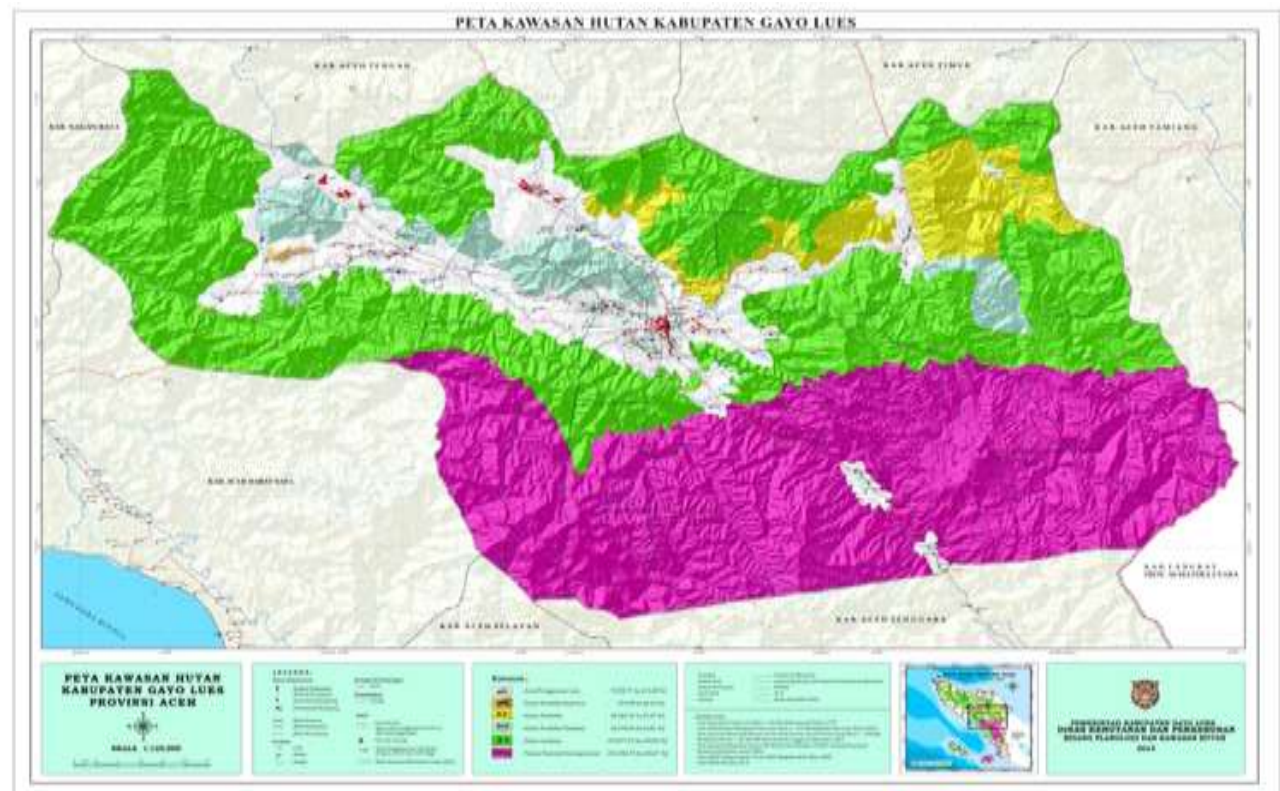

Source: PUPR and KPH 5, Gayo Lues Regency

Figure 4.2 Map of the Gayo Lues Regency Forest Area 


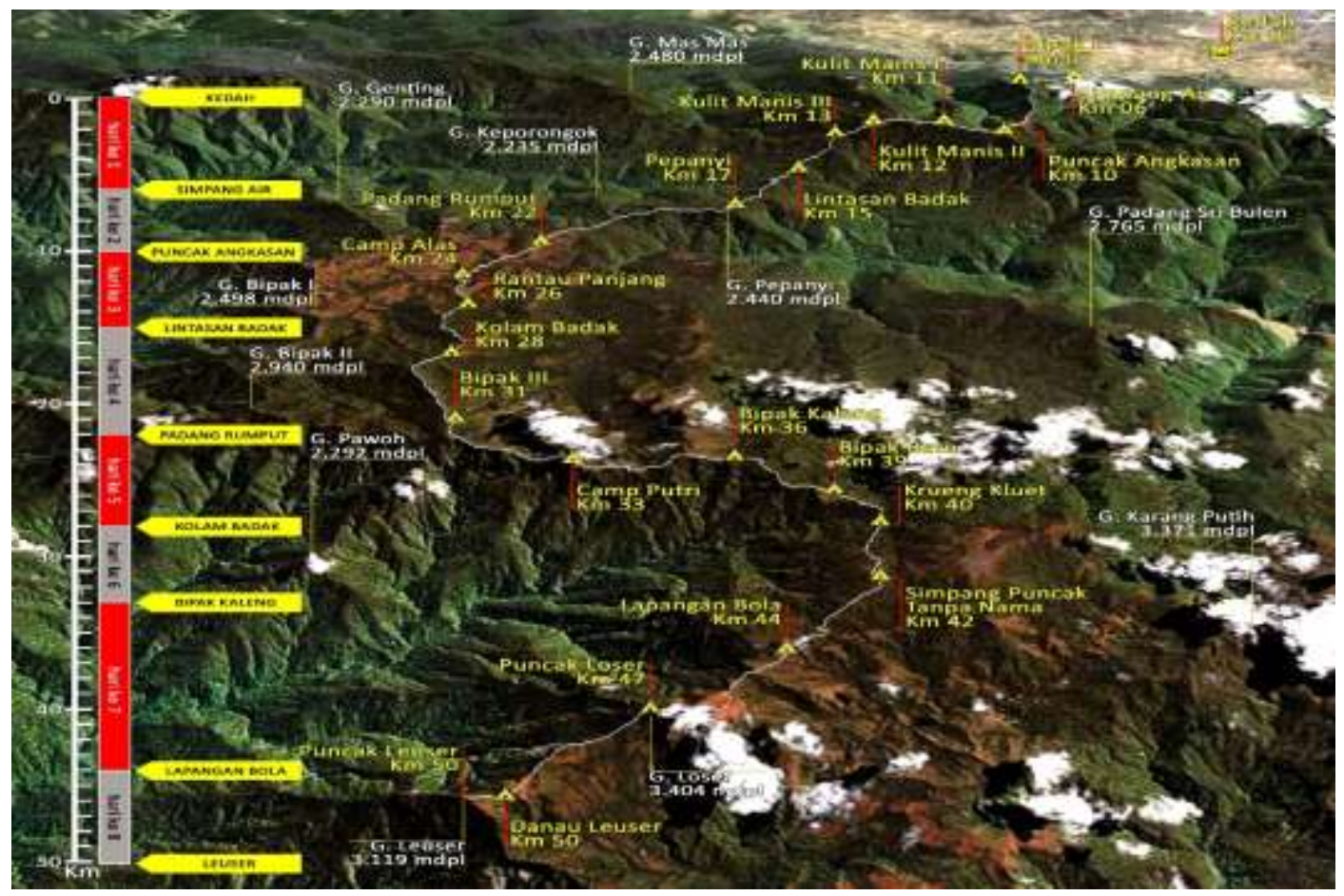

Source: SPTN Region III Blangkejeren Balai Besar Leuser Mountain National Park

Figure 4.3 Hiking Trails to Leuser Mountain, Gayo Lues Regency

The Kedah Natural Attraction Area has a unique natural resource in the form of a beautiful mountain panorama and also a clear river flow. Prominent natural resources are the presence of flora and fauna and water flow. Tourism activities that can be carried out include enjoying the beauty of nature, tracking, research / education and sports activities such as cross-country.

The Kedah Natural Attraction Area is an area that is free from residential areas. In this area there were no industries or other pollutants found because they were to enter the Kedah Natural Tourism Object area surrounded by community plantations and rice fields.

Based on field observations, the road conditions from the capital city of Gayo Lues, namely Blangkejeren to Penosan Sepakat Village are quite good. The road is made of asphalt with a width of $>3$ meters, while from Desa Penosan Sepakat to the Natural Attraction of Kedah the road is rocky. The distance traveled from Blangkejeren City to Penosan Sepakat Village is around $15 \mathrm{~km}$ and takes about 0.5 hours. Along the way to Penosan Sepakat Village from Blangkejeren City, it will pass through the villages and the rice fields of the population.

Kedah natural attractions can be reached from Blangkejeren by taking regular public transportation to the Kutapanjang / Blang Jerango route which is about $9 \mathrm{~km}$, then taking a machine tricycle to Penosan Sepakat Village for $5 \mathrm{~km}$, or by chartering public transportation from Blangkejeren to Penosan Sepakat Village. Tools supporting facilities that can be found within a $9 \mathrm{~km}$ radius are restaurants, markets and transportation. Whereas supporting infrastructure includes Puskesmas, Mosques and electricity networks. 
Determine the weights and ratings for each indicator in IFE and EFE. According to Rangkuti, determining the amount of weight and rating on each indicator can be used on a scale of 1,2,3. Ratings for each scale can be explained as follows:

a) Value $1=$ if the horizontal indicator is less important than the vertical indicator,

b) Value $2=$ if the horizontal indicator is as important as the vertical indicator, and

c) Value $3=$ if the horizontal indicator is more important than the vertical indicator

Table 4.6 Factors of Strength and Weaknesses (IFE)

\begin{tabular}{|c|l|c|}
\hline No & \multicolumn{1}{|c|}{ Strength } & Code \\
\hline 1 & Beautiful natural panorama & S1 \\
\hline 2 & Convenient and beautiful tourist location & S2 \\
\hline 3 & Interesting flora and fauna & S3 \\
\hline 4 & The air is clean and cool & S4 \\
\hline 5 & Safe to visit & S5 \\
\hline 6 & Entrance to Mount Leuser Climbing & S6 \\
\hline 7 & Camping location & S7 \\
\hline 8 & Friendly local community & S8 \\
\hline 9 & The absence of poaching & S9 \\
\hline 10 & Strategic location & $\mathrm{S} 10$ \\
\hline 11 & Adequate transportation & $\mathrm{S} 11$ \\
\hline 12 & Relatively low cost & $\mathrm{S} 12$ \\
& & \\
\hline
\end{tabular}

\begin{tabular}{|c|l|c|}
\hline No & \multicolumn{1}{|c|}{ Weakness } & Code \\
\hline 1 & Limited budget for developing tourist attraction & W1 \\
\hline 2 & Lack of travel marketing & W2 \\
\hline 3 & Unprofessional management & W3 \\
\hline 4 & $\begin{array}{l}\text { The land around the tourist attraction still belongs to the } \\
\text { population }\end{array}$ & W4 \\
\hline 5 & Lack of care for attractions and tourist facilities & W5 \\
\hline 6 & Lack of counseling to the community & W6 \\
\hline 7 & Lack of facilities and infrastructure & W7 \\
\hline
\end{tabular}

Table 4.7 IFE Weighting 


\begin{tabular}{|c|c|c|c|c|c|c|c|c|c|c|c|c|c|c|c|c|c|c|c|c|c|}
\hline Faktor & S1 & S2 & S3 & S4 & S5 & S6 & S7 & S8 & S9 & S10 & S11 & S12 & W1 & $\mathrm{W} 2$ & W3 & W4 & W5 & W6 & W7 & Rating & Bobot \\
\hline S1 & $\mathrm{X}$ & 2 & 2 & 2 & 2 & 2 & 2 & 2 & 2 & 2 & 2 & 2 & 1 & 1 & 1 & 1 & 1 & 1 & 2 & 30 & 0.037 \\
\hline S2 & 2 & $\mathrm{X}$ & 3 & 1 & 1 & 2 & 2 & 2 & 2 & 2 & 2 & 2 & 2 & 3 & 2 & 2 & 3 & 3 & 3 & 39 & 0.049 \\
\hline S3 & 2 & 3 & $\mathrm{X}$ & 2 & 1 & 2 & 3 & 3 & 1 & 3 & 3 & 3 & 2 & 3 & 3 & 3 & 3 & 3 & 3 & 46 & 0.057 \\
\hline S4 & 2 & 2 & 3 & $\mathrm{X}$ & 3 & 2 & 2 & 3 & 2 & 3 & 3 & 3 & 2 & 3 & 3 & 3 & 3 & 3 & 3 & 48 & 0.06 \\
\hline S5 & 3 & 3 & 2 & 3 & $\mathrm{X}$ & 2 & 2 & 2 & 3 & 1 & 2 & 3 & 2 & 3 & 2 & 2 & 1 & 3 & 2 & 41 & 0.051 \\
\hline \$6 & 2 & 2 & 2 & 2 & 2 & $\mathrm{X}$ & 2 & 3 & 1 & 3 & 3 & 2 & 3 & 2 & 3 & 3 & 3 & 3 & 3 & 44 & 0.055 \\
\hline S7 & 3 & 2 & 2 & 3 & 2 & 3 & $\mathrm{X}$ & 2 & 2 & 3 & 3 & 3 & 2 & 3 & 3 & 3 & 3 & 3 & 3 & 48 & 0.06 \\
\hline S8 & 3 & 3 & 3 & 3 & 1 & 3 & 2 & $\mathrm{X}$ & 3 & 3 & 3 & 3 & 3 & 3 & 3 & 3 & 3 & 3 & 3 & 51 & 0.063 \\
\hline S9 & 1 & 1 & 1 & 1 & 1 & 1 & 2 & 3 & $\mathrm{x}$ & 3 & 3 & 3 & 3 & 3 & 3 & 3 & 3 & 2 & 3 & 40 & 0.05 \\
\hline S10 & 3 & 2 & 3 & 3 & 2 & 2 & 2 & 3 & 3 & $\mathrm{X}$ & 2 & 3 & 1 & 3 & 3 & 3 & 3 & 3 & 1 & 45 & 0.056 \\
\hline S11 & 2 & 3 & 3 & 3 & 1 & 3 & 3 & 2 & 3 & 3 & $\mathrm{X}$ & 3 & 2 & 3 & 3 & 3 & 3 & 3 & 1 & 47 & 0.058 \\
\hline S12 & 3 & 3 & 3 & 3 & 2 & 2 & 2 & 3 & 3 & 3 & 3 & $\mathrm{X}$ & 2 & 3 & 3 & 3 & 3 & 3 & 3 & 50 & 0.062 \\
\hline W1 & 3 & 2 & 3 & 3 & 3 & 3 & 2 & 3 & 3 & 3 & 2 & 2 & $\mathrm{X}$ & 2 & 2 & 2 & 2 & 3 & 1 & 44 & 0.055 \\
\hline W2 & 1 & 2 & 2 & 3 & 2 & 1 & 2 & 3 & 3 & 3 & 1 & 1 & 1 & $\mathrm{X}$ & 1 & 2 & 2 & 2 & 1 & 33 & 0.041 \\
\hline W3 & 3 & 1 & 1 & 1 & 1 & 1 & 3 & 1 & 3 & 2 & 2 & 2 & 1 & 1 & $\mathrm{X}$ & 1 & 1 & 2 & 1 & 28 & 0.035 \\
\hline W4 & & & & & & & & & & & & & & & & & & & & & \\
\hline W5 & 3 & 2 & 3 & 3 & 3 & 3 & 3 & 3 & 3 & 3 & 3 & 2 & 1 & 2 & 1 & 1 & $\mathrm{X}$ & 3 & 3 & 45 & 0.056 \\
\hline W6 & 3 & 3 & 3 & 3 & 1 & 2 & 3 & 1 & 1 & 3 & 3 & 3 & 3 & 3 & 3 & 3 & 3 & $\mathrm{X}$ & 3 & 47 & 0.058 \\
\hline W7 & 1 & 1 & 1 & 3 & 3 & 1 & 3 & 2 & 3 & 3 & 2 & 3 & 1 & 3 & 3 & 3 & 3 & 3 & $\mathrm{X}$ & 42 & 0.052 \\
\hline TOTAL & 41 & 38 & 41 & 43 & 33 & 36 & 42 & 44 & 44 & 49 & 45 & 46 & 34 & 47 & 43 & 44 & 45 & 48 & 41 & 804 & 1 \\
\hline
\end{tabular}

Table 4.4. Opportunity and Threat Factors (EFE)

\begin{tabular}{|c|l|c|}
\hline No & \multicolumn{1}{|c|}{ Opportunities } & Code \\
\hline 1 & Location of flora and fauna research & $\mathrm{O} 1$ \\
\hline 2 & Student tourism locations & $\mathrm{O} 2$ \\
\hline 3 & Potential souvenir procurement & $\mathrm{O} 3$ \\
\hline 4 & Hiking location & $\mathrm{O} 4$ \\
\hline 5 & Entrance ticket procurement & $\mathrm{O} 5$ \\
\hline
\end{tabular}

\begin{tabular}{|c|c|c|}
\hline No & Threat & Code \\
\hline 1 & Possible landslide & T1 \\
\hline 2 & There are some more interesting tourist attractions & T2 \\
\hline 3 & Lack of visitor interest & T3 \\
\hline 4 & Unpredictable weather & T4 \\
\hline
\end{tabular}


Table 4.5 EFE Weighting

\begin{tabular}{|c|c|c|c|c|c|c|c|c|c|c|c|}
\hline Factor & O1 & O2 & O3 & O4 & O5 & T1 & T2 & T3 & T4 & $\begin{array}{c}\text { Total } \\
\text { Rating }\end{array}$ & Weight \\
\hline O1 & $\mathrm{X}$ & 2 & 2 & 2 & 3 & 1 & 3 & 2 & 2 & 17 & 0.1164384 \\
\hline O2 & 2 & $\mathrm{X}$ & 3 & 2 & 1 & 2 & 3 & 2 & 2 & 17 & 0.1164384 \\
\hline O3 & 3 & 2 & $\mathrm{X}$ & 2 & 3 & 3 & 3 & 2 & 3 & 21 & 0.1438356 \\
\hline $\mathrm{O} 4$ & 1 & 1 & 2 & $\mathrm{X}$ & 2 & 1 & 3 & 3 & 3 & 16 & 0.109589 \\
\hline $\mathrm{O} 5$ & 2 & 2 & 2 & 2 & $\mathrm{X}$ & 2 & 2 & 1 & 2 & 15 & 0.1027397 \\
\hline $\mathrm{T} 1$ & 1 & 1 & 3 & 1 & 3 & $\mathrm{X}$ & 3 & 2 & 2 & 16 & 0.109589 \\
\hline $\mathrm{T} 2$ & 2 & 2 & 3 & 1 & 2 & 2 & $\mathrm{X}$ & 1 & 3 & 16 & 0.109589 \\
\hline $\mathrm{T} 3$ & 1 & 1 & 1 & 1 & 1 & 2 & 1 & $\mathrm{X}$ & 3 & 11 & 0.0753425 \\
\hline T4 & 1 & 1 & 3 & 2 & 3 & 1 & 3 & 3 & $\mathrm{X}$ & 17 & 0.1164384 \\
\hline TOTAL & 13 & 12 & 19 & 13 & 18 & 14 & 21 & 16 & 20 & 146 & 1 \\
\hline
\end{tabular}

Table 4.6 Calculation of IFE and EFE Scores

\begin{tabular}{|c|c|c|c|c|c|c|c|}
\hline Code & Weight & Rating & Score & Code & Weight & Rating & Score \\
\hline S1 & 0.03731343 & 4 & 0.149254 & O1 & 0.116438 & 4 & 0.465753 \\
\hline S2 & 0.04850746 & 4 & 0.19403 & $\mathrm{O} 2$ & 0.116438 & 4 & 0.465753 \\
\hline S3 & 0.05721393 & 3 & 0.171642 & $\mathrm{O} 3$ & 0.143836 & 4 & 0.575342 \\
\hline S4 & 0.05970149 & 4 & 0.238806 & $\mathrm{O} 4$ & 0.109589 & 3 & 0.328767 \\
\hline S5 & 0.05099502 & 4 & 0.20398 & $\mathrm{O} 5$ & 0.10274 & 3 & 0.308219 \\
\hline S6 & 0.05472637 & 4 & 0.218905 & \multicolumn{3}{|c|}{ Total } & 2.14384 \\
\hline S7 & 0.05970149 & 3 & 0.179104 & Code & Weight & Rating & Score \\
\hline S8 & 0.06343284 & 4 & 0.253731 & T1 & 0.109589 & -3 & -0.32877 \\
\hline S9 & 0.04975124 & 4 & 0.199005 & T2 & 0.109589 & -4 & -0.43836 \\
\hline $\mathrm{S} 10$ & 0.05597015 & 3 & 0.16791 & T3 & 0.075342 & -2 & -0.15068 \\
\hline S11 & 0.05845771 & 2 & 0.116915 & $\mathrm{~T} 4$ & 0.116438 & -4 & -0.46575 \\
\hline $\mathrm{S} 12$ & 0.06218905 & 3 & 0.186567 & \multicolumn{3}{|c|}{ Total } & -1.3836 \\
\hline \multicolumn{3}{|c|}{ Total } & 2.27985 & \multicolumn{3}{|c|}{ O-T } & 0,76027 \\
\hline Code & Weight & Rating & Score & & & & \\
\hline W1 & 0.05472637 & -1 & -0.05473 & & & & \\
\hline W2 & 0.04104478 & -2 & -0.08209 & & & & \\
\hline W3 & 0.03482587 & -2 & -0.06965 & & & & \\
\hline W4 & 0.04477612 & -4 & -0.1791 & & & & \\
\hline W5 & 0.05597015 & -4 & -0.22388 & & & & \\
\hline W6 & 0.05845771 & -3 & -0.17537 & & & & \\
\hline W7 & 0.05223881 & 2 & 0.104478 & & & & \\
\hline \multicolumn{3}{|c|}{ TOTAL } & -0.6803 & & & & \\
\hline \multicolumn{3}{|c|}{ S-W } & 1,5995 & & & & \\
\hline
\end{tabular}




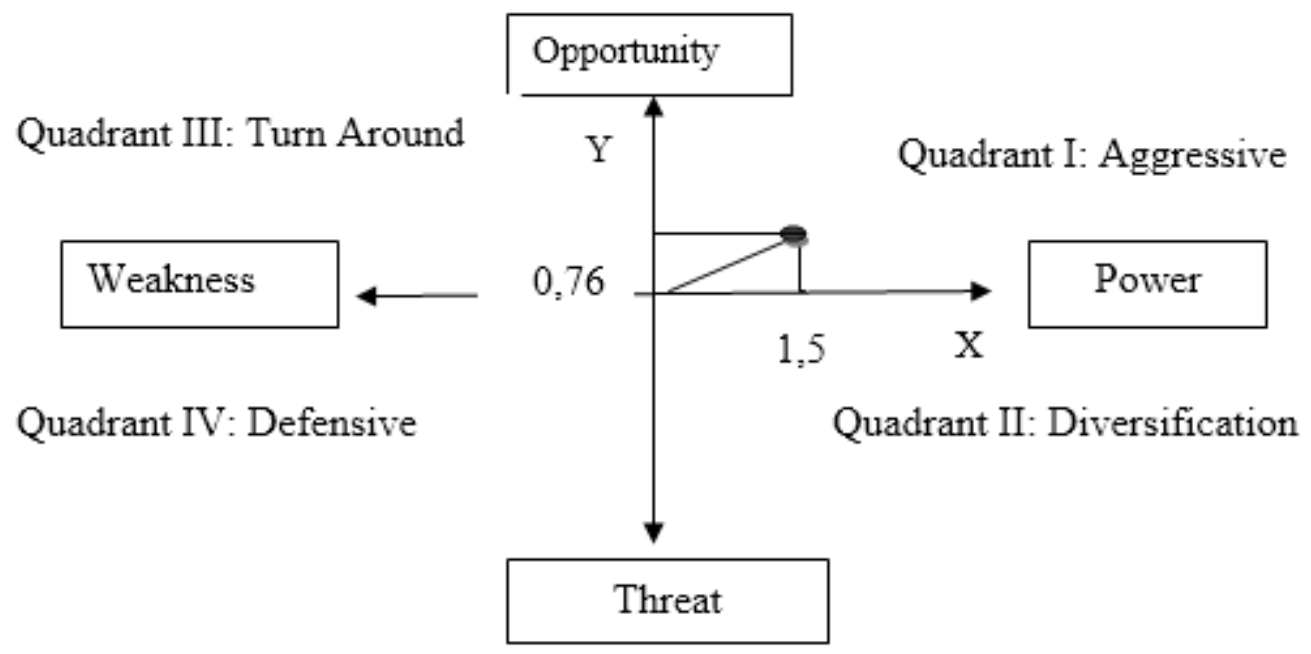

Figure 4.4 SWOT Diagram

Kedah Nature Tourism Object located in the Penosan Sepakat Village can be offered as an alternative tourist destination for local and foreign tourists who want a new tourist spot that is still very natural. Besides Kedah Nature Tourism Object can also be used as a tourist destination for schools in Blangkejeren City, Kutapanjang District and Blangjerango District who want to do outdoor activities. The government can also create a cross-race event at the Kedah Natural Attraction to attract the enthusiasm of the community and at the same time promote environmental care programs. The Kedah Natural Attraction Area can also be offered as a research location for flora and fauna for schools or universities and institutions around the area.

The implementation of this strategy will have a good impact on the development of the Kedah Nature Tourism Object as a special interest tourist destination and will also help improve the economy of the surrounding community because with the increasing number of visitors it will create a new market that will encourage the economy of the surrounding community. With the increase in the community's economy due to the existence of Kedah Nature Tourism Objects, the daily needs of the community are no longer dependent on forest products so that the sustainability of the forests around the area will be maintained.

Wollenberg et al. (2004) states that currently Indonesia has a great opportunity to overcome poverty by paying attention to the forms of poverty problems in forest areas, how government interventions can overcome these problems across sectors, and to monitor changes that occur. Paying attention to forests and people in forest areas is absolutely necessary in poverty alleviation in Indonesia.

The existence of a trend back to nature that stimulates natural tourism investment lately needs to be addressed with firm and wise direction from decision makers (the government) and high awareness from managers so that ecological and economic functions are guaranteed. Pricing must involve the government because this has a broad impact on environmental sustainability and the community at large. Subsidies are still very much needed to attract investment in Indonesia's natural tourism and most importantly the development of natural tourism must be able to raise the welfare of the surrounding community (Nurrochmat, 2005). 


\section{Conclusion}

The forms of community participation in the development of the Kedah Natural Tourism Object area are:

a) Participation in incentives, namely community participation in the form of personnel, as evidenced by his daily life as a guard at the entrance to Kedah Nature Tourism Objects, parking officers, security officers, tour guides for tourists who will be tracking and hiking to Mount Leuser totaling 20 people and building facilities support in the area of Kedah Natural Tourism Objects, Blang Jerango District, such as a selfie (take picture).

b) Participation in initiatives, namely community participation in the Kedah natural tourism object area in the form of skills and skills, aimed at the existence of restaurants / canteens and small kiosks that sell food and drinks for tourists while enjoying the natural beauty of the mountains.

c) Interactive participation, namely community participation in the Kedah Nature Tourism object area in the form of ideas, as indicated by participation to participate in socialization meetings, tourism HR training held by the local government and to participate in promoting Tourism Objects in Gayo Lues Regency, especially Natural Tourism Objects Kedah by carrying out events to attract tourists both local and foreign.

Based on the results of the SWOT analysis, Kedah Nature Tourism Objects shows that the position of the Kedah Nature Tourism Objects is in quadrant 1, this indicates that Kedah Nature Tourism Objects are in a very favorable position where the power possessed by Kedah Nature Tourism Objects such as the entrance to the Leuser Mountain which is one of the World Heritage has interesting flora and fauna and beautiful natural panorama and the air is still cool and clean can cover weaknesses and threats such as lack of facilities and infrastructure, unprofessional management and so forth. This position also makes Kedah Nature Tourism Objects can take all the opportunities available such as making Kedah Natural Tourism Objects a place for flora and fauna research for students and potential souvenirs, and so on.

\section{References}

Balai Besar Taman Nasional Gunung Leuser. 2018. Buku Warisan Hutan Tropis Sumatera Damanik, Janianton dan Helmut F. Weber. 2006. Perencanaan Ekowisata dari Teori ke Aplikasi. Indonesia: ANDI

F. Ross, Glenn. 1998. Psikologi Pariwisata. Jakarta: Yayasan Obor Indonesia

Hartono, Hari. 1974. Perkembangan Pariwisata, Kesempatan Kerja, dan Permasalahannya. Prisma

J. Spillane, James, 1987. Ekonomi Pariwisata Sejarah dan Prosesnya. Yogyakarta: Kanisius

Jurnal, Deviyanti, Dea. 2013. Studi Tentang Partisipasi Masyarakat dalam Pembangunan Dikelurahan Karangjati Kecamatan Balikpapan Tengah

Jurnal, Dewi, Oktami. 2013. Partisipasi Masyarakat dalam Pengembangan Objek Wisata Bahari Di Pulau Kapoposang Kabupaten Pangkajene dan Kepulauan 
M. Baiquni dan Wardiyanto. 2011. Perencanaan Pengembangan Pariwisata. Bandung: Lubuk Agung

Mahi, Ali Kabul.2016. Pengembangan Wilayah Teori dan Aplikasi. Jakarta: Kencana

Mardalis. 1995. Metode Penelitian Suatu Pendekatan Proposal. Jakarta: Bumi Aksara

Marpaung. Happy. 2002. Pengetahuan Kepariwisataan. Bandung : Penerbit Alfabeta

Muljadi A. J dan Andri Warman. 2014. Kepariwisataan dan Perjalanan. Jakarta: PT RajaGrafindo Persada

Oka A,Yoeti. 2008. Perencanaan dan Pengembangan Pariwisata. Jakarta: PT. Pradnya Paramita. , Ekonomi Pariwisata Introduksi, Informasi dan Aplikasi. Jakarta: Kompas Media Nusantara

Pendit, N.S. 1999. Ilmu Pariwisata Sebuah Pengantar Perdana. PT. Anem Kosong Anem

Rangkuti, Freddy.2006. Analisis SWOT Teknik Membedah Kasus Bisnis. Jakarta: PT Gramedia Pusaka Utama

Ridwan, Mohammad. 2012. Perencanaan dan Pengembangan Pariwisata. Medan: PT SOFMEDIA

Sirojuzilam. 2011. Problematika Wilayah Kota dan Daerah. Medan: USU Pres

Soekadijo, R. G. 1997. Anatomi Pariwisata. Jakarta: PT Gramedia Pusaka Utama

Spillane, J J. 1994. Pariwisata Indonesia Siasat Ekonomi dan Rekayasa Kebudayaan. Yogyakarta: Kanisius

Sucic, Mirela. 2009. Public Private Partnership-Postulate for Competitive Tourism Development. Politechnics of Sibenik Departemen Management

Sudjana, Nana dan Awal Kusumah. 1992. Proposal Penelitian di Perguruan Tinggi. Bandung: Sinar Baru

Sugiharto. 2006. Pembangunan dan Pengembangan Wilayah. Medan: USU Press

Suwantoro, Gamai. 1997. Dasar-Dasar Pariwisata. Yogyakarta: ANDI

Umar, Husein. 2011. Metode Penelitian untuk Skripsi dan Tesis Bisnis. Jakarta: Rajawali Pers

Wardiyanta. 2006. Metode Penelitian Pariwisata. Yogyakarta: A 